\title{
The Effect of Leadership Style and Competence on Employee Performance
}

\author{
I. Made Sulantara, Putu Kepra Mareni, I. Ketut Setia Sapta, and Ni Kadek Suryani
}

\begin{abstract}
Government officials regions must have the maximum capacity in managing human resources in their regions. Local governments, either individually, in groups or institutions, are trying to improve the quality and quantity of work in order to improve their performance. This study aims to determine the effect of leadership style, competence on organizational commitment. To determine the effect of leadership style, competence and commitment to performance. To find out the role of organizational commitment in mediating the influence of leadership style and competence on performance at the Office of Investment and One Stop Services (DPMPTSP) Denpasar City Bali, Indonesia. Data collection using a questionnaire. The number of samples used was 77 people using purposive sampling method. The data analysis technique used SEM-PLS. The results showed that leadership style had a positive effect on organizational commitment. Competence has a positive effect on commitment organizational, leadership style has a positive effect on employee performance, competence has a positive effect on employee performance, organizational commitment has a positive effect on employee performance, organizational commitment can mediate the influence of leadership style on employee performance, organizational commitment can mediate the influence of competence on employee performance.
\end{abstract}

Index Terms - leadership style, competence, commitment, performance.

\section{INTRODUCTION}

Job assessment for government officials is useful for assessing the quantity, quality and efficiency of services, leadership style, and adjustments to organizational budgets. But the problem that arises is whether the work appraisal that has been carried out so far has described the actual performance of the government bureaucracy. This will be very much determined by the sharpness in determining the methods and indicators used.

The main task of government organizations is to lead their people to the gate of welfare and prosperity and freedom, these tasks can be grouped into 3, namely as public service related to community service, growth / development as a motor of development (economic growth, poverty alleviation, distribution of income and basic needs) and empowering (empowerment of human resources and technology). With these heavy duties, the government's position is as a public figure, where in carrying out tasks it must always be based on the rules of the game which are

Published on September 10, 2020.

I. Made Sulantara, Mahasaraswati University of Denpasar, Indonesia. (e-mail: made.tayes@gmail.com)

Putu Kepra Mareni, Mahasaraswati University of Denpasar, Indonesia. (e-mail: pkepramareni@yahoo.co.id)

I. Ketut Setia Sapta, Mahasaraswati University of Denpasar, Indonesia. (e-mail: ketutsetiasapta@ ${ }^{\circledR}$ ahoo.com)

Ni Kadek Suryani, Mahasaraswati University of Denpasar, Indonesia.

(corresponding e-mail: nksryani@gmail.com) packaged in regulations in the form of legislation, central and local government regulations.

Human resources play a major role in every company activity. In human resource management, the competency is used as a provision for someone in searching, researching, and evaluating information that is used to complete the work, so that human resources have the competence to be able to explore the potential of other resources owned by the institution or company [21]. The number of facilities and infrastructure as well as resources, without the support of human resources, the company's activities will not run well. Thus, human resources are the main keys that determine the success of the company's activities. In achieving employee goals, adequate human resource competence is needed in encouraging employees to achieve certain goals. The Denpasar City Investment Service and One Stop Integrated Service is one of the government agencies that provides public services, which do not escape the public's spotlight regarding employee performance.

To realize maximum employee performance, the agecy has not been able to achieve because it still faces obstacles such as those related to competence, namely employees with technical backgrounds and English literature are placed in the general section, there are employees with a background in socio-political education who are placed in the financial department. Balinese literary education was placed in the licensing and non-licensing services section B, agriculture graduates were placed in the field of service $C$, so that educational inconsistencies had an impact on understanding the tasks they were assigned to. Phenomena related to organizational commitment at the Denpasar City Investment and One Stop Integrated Service Office include that employees are still skipping work, going home not on time, not attending morning briefing and the afternoon break exceeds the predetermined time.

Previous empirical studies on the influence of leadership style and competence on performance through mediation of organizational commitment are still very limited and some of them show non-uniform results or experience gaps (research gaps) with concepts or theories.

Based on the phenomena and these research gap, it provides clear direction on the formulation of the research problem are : does leadership style affect organizational commitment. Does competence affect organizational commitment. Does leadership style affect performance? Does competency affect performance. Does organizational commitment affect performance. Does organizational commitment can mediate the influence of leadership style on performance. Can organizational commitment mediate the influence of competence on performance at the Denpasar City Investment and One Stop Integrated Service (DPMPTSP) Office? 


\section{LITERATURE REVIEW}

Leadership has a strong influence on the survival of an organization. Kreitner and Kinicki suggest that leadership is a process where an individual influences others to achieve common goals [9]. Gibson et. al. suggest that leadership is an attempt to use influence to motivate individuals to complete several goals of an organization [6].

Robbins and Judge suggest that leadership style is divided into three models, namely: (1) transactional leadership style, (2) transformational leadership style and (3) Laissez-fire leadership style [15]. Transactional leadership is a leader who guides or motivates their followers who are directed towards the goals set by explaining the roles and tasks required while transformational leadership is a leader who can inspire his followers to go beyond their own interests and who is capable of profound and extraordinary influence. towards his followers. Meanwhile, Lor argues that Laissez-Faire leadership is a type of free-control leadership that describes a leader who as a whole gives employees freedom in making decisions and completing work according to the employee's way [10].

The results of research by Walumbwa and Lawler found that leadership style has a positive and significant effect on the level of organizational commitment [24]. The same research results are shown by Sartika [17]. Based on the description above, the research hypothesis can be formulated as follows: H1: Leadership Style Has a Positive Effect on Organizational Commitment.

Byars and Rue describe that competence is defined as a trait or characteristic needed by an office holder in order to carry out a position properly, or it can also mean that the characteristics / characteristics of a person are easily seen including the knowledge, expertise, and behavior that allows. to perform [2]. As a consequence of this competency definition, the definition of competence refers to the ability of people to fulfill the requirements of their current or future roles. Thus, competence can also predict future performance because competence is an ongoing characteristic that generally cannot be lost [1].

Lotunani in his research found that competence has a positive and significant effect on organizational commitment [11]. Employees who have good competence will retain employees to continue working by providing salaries, benefits, and others that are in accordance with their competencies. Reciprocity is appropriate between the company and the employees making employees commit to the company where they work [5]. Research by Yamali [24] found that competence has a positive effect on organizational commitment. Based on the description above, the research hypothesis can be formulated as follows: H2: Competence has a positive effect on Organizational Commitment.

Leadership with democratic, authoritarian or complementary styles has their way of carrying out their leadership. What employees want to achieve is also different. The leadership style of an organization or company leader can affect employee loyalty to the organization or company and the quality of performance. If the leader wants subordinates to trust each other, the leader must be able to trust them. A leader becomes a role model and role model for his subordinates. The behavior or attitude of a leader can be said to be a role model and motivation for employees to do work. In general, subordinates only follow what their leaders say by $80 \%$ [23].

Rivai [14] states that leadership style plays a very important role, it can even be said to be very decisive in achieving the goals previously set. Kasmir [8] also states that leadership style is one of several factors that affect employee performance. The leadership style between authoritarian and democratic leadership is certainly different. Through the leadership style, a leader can determine how to direct employees to achieve goals. Hakim Azizi's [7] research results concluded that leadership style has a positive and significant effect on employee performance. Similar results are shown by Tampi [22]. Based on these description the following research hypothesis can be formulated: H3: Leadership Style Has a Positive Effect on Performance

Competence is a basic characteristic of a person that allows them to produce superior performance in their work. Competence is needed by the organization to support the successful implementation of work, and some organizations set the competency standards needed for their employees. Every organization and company will try to improve the performance of its employees to achieve the organizational goals that have been determined, one of which is by increasing employee competence [20].

Competence is a set of knowledge, skills, and behaviors that employees must possess, appreciate, master and actualize in carrying out them professionally. Competence describes what people do in the workplace at various levels and specifies the standards for each level, identifies the characteristics of the knowledge and skills needed by the individual to enable them to carry out their duties and responsibilities effectively so as to achieve professional quality standards in work.

Competence is a fundamental characteristic of each individual associated with criteria referenced to superior or effective performance in a job or situation. The underlying characteristics mean that competence is part of a person's personality that has been embedded and lasts a long time and can predict behavior in various tasks and work situations. Associated cause means that competence causes or predicts behavior and performance. Criteria benchmarks mean that competence actually predicts who does something well or badly, as measured by specific criteria or standards. These are a number of characteristics that underlie a person and show how to act, think, or generalize about a situation in the long term.

There are five types of competency characteristics, namely: (1) motives, is consistently thought of and desired, which causes one's actions; (2) traits, physical characteristics and consistent responses to situations or information; (3) the concept of self, attitudes, values or a picture of one's self; (4) knowledge, information owned by someone in specific areas; (5) skills, skills someone to perform to a certain physical or mental tasks. The results of the research by Dhermawan et al. [3] show that competence 
has a positive and significant effect on employee performance. Based on the description above, the following research hypothesis can be formulated: H4 Competence has a positive effect on performance.

Employees with high organizational commitment have different attitudes than those with low commitment. High organizational commitment generate job performance, low absenteeism, and low employee turnover. Highly committed employees will have high productivity [12]. Conversely, low employee commitment has a negative impact. Every organization will experience difficulties if employee commitment is low. Employees with low commitment will not give the best to the organization and will easily leave the organization.

There are several studies conducted by researchers that examine the relationship between organizational commitment and performance.research results Efliani [4]. Furthermore, research also carried out by Taurisa and Ratnawati [23] found that there was a direct influence between organizational commitment and employee performance. Similar results were carried out by Supriyanto [18] and Mekta. Based on the description above, the research hypothesis can be formulated as follows: H5: Organizational Commitment has a Positive Effect on Performance. Kasmir [8] also states that leadership style is one of several factors that affect employee performance. The leadership style between authoritarian and democratic leadership is certainly different. Through the leadership style, a leader can determine how to direct employees to achieve goals.

Employees with high organizational commitment have different attitudes than those with low commitment. High organizational commitment results in work performance, low absenteeism, and low employee turnover. Highly committed employees will have high productivity. The research results of Azizi concluded that leadership style has a positive and significant effect on employee performance. Safitri's research [16] states that organizational commitment can mediate the influence of leadership style on performance. Based on the description above, the following research hypothesis can be formulated: H6: Organizational commitment can mediate the influence of leadership style on performance.

Competence is a basic characteristic of a person that enables them to produce superior performance in their work. Competence is needed by the organization to support the successful implementation of work, and some organizations set the competency standards needed for their employees.

Every organization and company will try to improve the performance of its employees to achieve the organizational goals that have been determined, one of which is by increasing employee competence. Competence is a set of knowledge, skills, and behaviors that employees must possess, appreciate, master and actualize in carrying out them professionally. Employees with high organizational commitment have different attitudes than those with low commitment. High organizational commitment results in work performance, low absenteeism, and low turnover employee. Highly committed employees will have high productivity.

Previous research was conducted by Supriyanto (2015) [18] with the title Effect of Compensation, Competence and Organizational Commitment on Satisfaction and Performance, the results of his research found that there was a positive and significant influence between organizational commitment to employee performance. The results of Yamali's (2017) [26] research show that organizational commitment is able to mediate the influence of competence on performance through organizational commitment. Based on the description above, the following research hypothesis can be formulated: H7: Organizational commitment can mediate the effect of competence on performance.

\section{RESEARCH METHODS}

This research uses a quantitative method research design to test models and instruments that have been developed by previous researchers through inferential statistics, namely by using Structural Equation Modeling, with theapproach Partial Least Square (PLS). The location of the research was carried out at the Office of Investment and One Stop Services in Denpasar City, Bali Province, Indonesia with sample 77 civil servants permanent staff. This study uses a Likert scale questionnaire for data collection with four variables, namely leadership style using indicators adopted from House in Suwatno [19], competence using indicators from Moeheriono [13], organizational commitment using indicators from Sinambung and performance refers to PP NO. 10 Year 1979.

\section{RESULTS AND DISCUSSION}

Before the questionnaire is used as a research instrument, it is first tested for validity and reliability, the results of the validity test are shown in Table 1 .

Based on Table 1, it can be seen that all items to measured are valid and fit for use as research instruments.

The test results of Cronbach's Alpha with a value of 0.60. From the processing of SPSS version 22.0, the coefficient is obtained Cronbach's alpha as shown in the following Table 2 with the coefficient Cronbach's Alphaon all variables is above 0,60 . This means that the questionnaire is reliable.

Discriminant validity is done to ensure that each concept of each latent variable is different from other variables. The model have good discriminant validity if each indicator loading value of a latent variable has a loading value that is greater than the loading value if it is correlated with other latent variables.testing results Discriminant validity in Table 3.

Discriminant Validity test is shown on Table 3. It informed that from the results of all four variable has a value above $0.50 \mathrm{AVE}$ and all variables have the root AVE value which is better than the correlation coefficient between one variable and another so said that the data has good discriminant validity. 
TABLE 1: VALIDITY AND RELIABILITY TEST RESULTS

\begin{tabular}{|c|c|c|}
\hline Code & $\begin{array}{c}\text { Value Correlation Product } \\
\text { Moment }\end{array}$ & Information \\
\hline $\mathrm{X} 1.1$ & 0.918 & Valid \\
\hline $\mathrm{X} 1.2$ & 0.884 & Valid \\
\hline $\mathrm{X} 1.3$ & 0.865 & Valid \\
\hline $\mathrm{X} 1.4$ & 0.925 & Valid \\
\hline $\mathrm{X} 2.1$ & 0.991 & Valid \\
\hline $\mathrm{X} 2.2$ & 0.979 & Valid \\
\hline $\mathrm{X} 2.3$ & 0.945 & Valid \\
\hline X2.4 & 0.979 & Valid \\
\hline $\mathrm{X} 2.5$ & 0.969 & Valid \\
\hline Y1.1.1 & 0.884 & Valid \\
\hline $\mathrm{Y} 1.1 .2$ & 0.884 & Valid \\
\hline Y1.1.3 & 0.884 & Valid \\
\hline Y1.2.1 & 0.848 & Valid \\
\hline $\mathrm{Y} 1.2 .2$ & 0.796 & Valid \\
\hline Y1.2.3 & 0.677 & Valid \\
\hline Y1.3.1 & 0.854 & Valid \\
\hline Y1.3.2 & 0.826 & Valid \\
\hline $\mathrm{Y} 1.3 .3$ & 0.854 & Valid \\
\hline Y2.1.1 & 0.765 & Valid \\
\hline Y2.1.2 & 0.732 & Valid \\
\hline Y2.1.3 & 0.730 & Valid \\
\hline Y2.2.1 & 0.795 & Valid \\
\hline $\mathrm{Y} 2.2 .2$ & 0.707 & Valid \\
\hline Y2.2.3 & 0.702 & Valid \\
\hline Y2.3.1 & 0.809 & valid \\
\hline Y2.3.2 & 0.818 & invalid \\
\hline Y2.3.3 & 0.716 & valid \\
\hline Y2.3.4 & 0.799 & valid \\
\hline Y2.4.1 & 0,753 & valid \\
\hline Y2.4.2 & 0.626 & valid \\
\hline Y2.4.3 & 0.696 & valid \\
\hline Y2.5.1 & 0.791 & valid \\
\hline Y2.5.2 & 0.679 & valid \\
\hline Y2.5.3 & 0.673 & valid \\
\hline Y2.5.4 & 0.733 & Valid \\
\hline
\end{tabular}

TABLE 2: RELIABILITY TEST

\begin{tabular}{|l|c|c|}
\hline \multicolumn{1}{|c|}{ Variable } & Cronbach's Alpha & Description \\
\hline Leadership style & 0.919 & Reliable \\
\hline Competency & 0.879 & Reliable \\
\hline $\begin{array}{l}\text { Organizational } \\
\text { commitment }\end{array}$ & 0.941 & Reliable \\
\hline Employee performance & 0.946 & Reliable \\
\hline
\end{tabular}

Composite Reliability, criteria validity and reliability can also be seen from the reliability value of a variable and the Average Variance Extracted (AVE) value of each variable. The variable is said to have good reliability if the value is composite reliability above 0.70 and AVE is above 0.50 .

Table 4 informs that all variables meet composite reliability because their value is above the recommended number, which is above 0.7 which has met the criteria for being reliable. Based on the results of the overall evaluation, both convergent, discriminant validity, composite reliability, which have been described above, it can be concluded that indicators as measures of latent variables are valid and reliable.

On the inner model test or structural model is tested to see the relationship between variables, the significance value and the $\mathrm{R}$-square of the research model. The structural model was evaluated using the R-square for the dependent variable t test as well as the significance of the structural path parameter.

TABLE 3: DISCRIMINANT VALIDITY

\begin{tabular}{|c|c|c|c|c|c|c|}
\hline \multicolumn{3}{|l|}{ AVE } & \multicolumn{4}{|c|}{ Correlation } \\
\hline & AVE & $\sqrt{A V E}$ & $\begin{array}{l}\text { leadership } \\
\text { style (X1) }\end{array}$ & $\begin{array}{c}\text { employee } \\
\text { performance } \\
(\mathrm{Y} 2)\end{array}$ & $\begin{array}{l}\text { Commitment to the } \\
\text { organization (Y1) }\end{array}$ & $\begin{array}{c}\text { Work } \\
\text { Motivation } \\
\text { (X2) }\end{array}$ \\
\hline leadership style(X-1) & 0.944 & 0.972 & 1 & & & \\
\hline employee performance $\left(\mathrm{Y}_{0.896}\right.$ & 2) & 0.947 & 0.733 & 1 & & \\
\hline organizational commitment $\left(\mathrm{Y}_{0.9571}\right.$ & 0.915 & & 0.622 & 0.805 & 1) & \\
\hline Competence $\left(\mathrm{X}_{0.9940 .7090 .818}\right.$ & 0.989 & & 0.399 & & 2) & 1 \\
\hline
\end{tabular}

TABLE 4: COMPOSITE RELIABILITY

\begin{tabular}{|c|c|}
\hline TABLE 4: COMPOSITE RELIABILITY \\
\hline Variable & Composite Reliability \\
\hline Leadership style $\left(\mathrm{X}_{1}\right)$ & 0.944 \\
\hline Competence $\left(\mathrm{X}_{2}\right)$ & 0.896 \\
\hline Organizational commitment $\left(\mathrm{Y}_{1}\right)$ & 0.915 \\
\hline Employee performance $\left(\mathrm{Y}_{2}\right)$ & 0.989 \\
\hline
\end{tabular}

Based on Fig. 1 informed that the covariance of the indicator measurement is influenced by the latent construct or reflects the variation of the unidimensional construct which is depicted in an ellipse shape with several arrows from the construct to the indicator. This model hypothesizes that changes in latent constructs affect changes in indicators. In this model, there are two exogenous variables, namely leadership style and competence and two endogenous variables, namely organizational commitment and employee performance. Model assessment with PLS begins by looking at the R-square for each dependent latent variable. Changes in the R-square value can be used to assess the effect of certain exogenous latent variables on endogenous latent variables that have a substantive effect. The structural model is evaluated by paying attention to the $\mathrm{Q}^{2}$ predictive relevance model which measures how well the observation value is generated by the model. $\mathrm{Q}^{2}$ is based on the coefficient of determination of all dependent variables. The quantity of $\mathrm{Q}^{2}$ has a value with a range of $0<\mathrm{Q}^{2}<1$, the closer to the value of 1 , the better the model. Table 5 shows the results of theestimation R-square using Smart PLS.

Table 5 shows the value R-square variable organizational commitment at 0.773 and 0 square value, the greater the ability of the exogenous variables to be explained by the endogenous variables so that the better the structural equation 0.764 employee performance variables.

TABLE 5: R-SQUARE VALUE
\begin{tabular}{|l|l|}
\hline Variable & $R$-Square \\
\hline organizational commitment (Y1) & 0.773 \\
\hline Employee Performance (Y2) & 0.764 \\
\hline
\end{tabular}




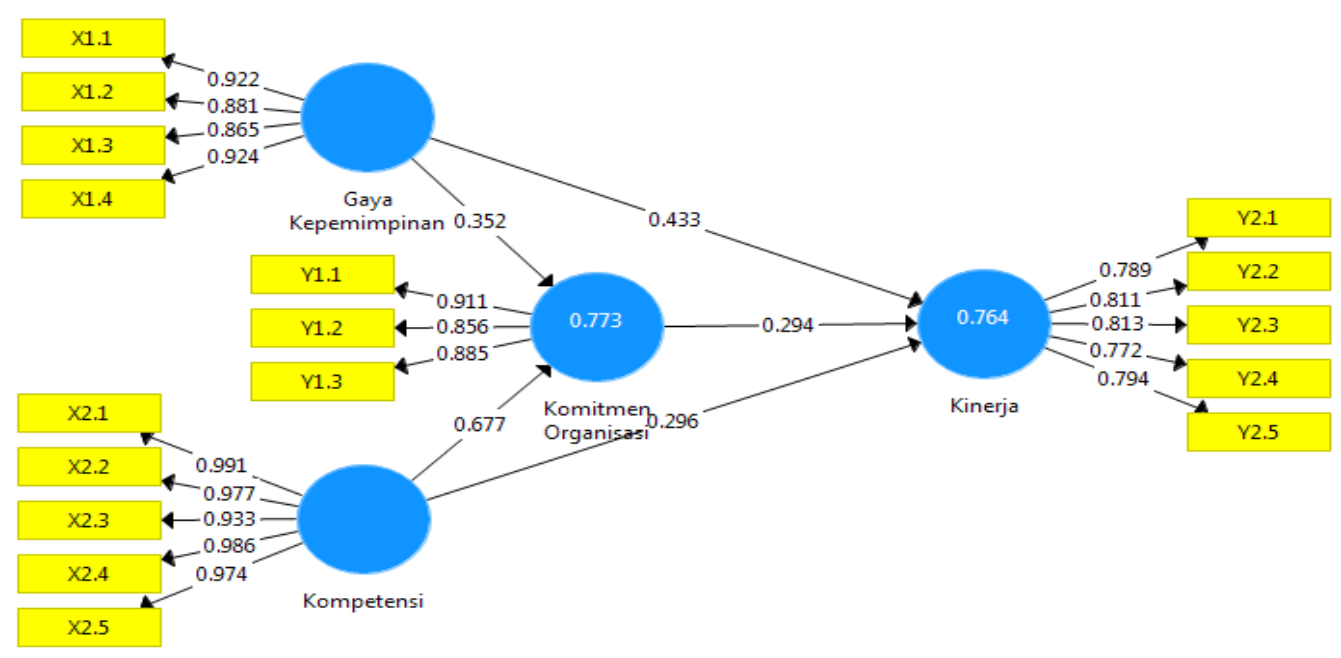

Fig. 1: Structural Model (Inner Model).

Apart from using the R-square, the goodness of fit of the model is also measured using the Q-Square predictive relevance for the structural model, measuring how well the observed value is generated by the model and also its parameter estimation. The results of the calculation of $\mathrm{Q}$ Square Predictive Relevance $\left(\mathrm{Q}^{2}\right)$ show a value of 0.946 , which means that the model shows good observation, where $94.6 \%$ of the relationship between variables can be explained by the model, while the rest $(5.4 \%)$ is an error factor or other factors not included in the Research Model. The evaluation inner model measured based on Q Square
Predictive Relevance $\left(\mathrm{Q}^{2}\right)$ and Goodness of Fit (GoF) above shows that the model formed by the constructs has a very good model category. The results of hypothesis testing are shown in the following Table 6.

The test results of the mediating role of work commitment variable $\left(\mathrm{Y}_{1}\right)$ between leadership style $\left(\mathrm{X}_{1}\right)$ on employee performance $\left(\mathrm{Y}_{2}\right)$ and the mediating role of organizational commitment variables $\left(\mathrm{Y}_{1}\right)$ between competencies $\left(\mathrm{X}_{2}\right)$ on employee performance $\left(\mathrm{Y}_{2}\right)$ the results of the analysis are presented in Table 7 as follows:

TABLE 6: RESULT OF HYPOTHESES TESTING

\begin{tabular}{|c|c|c|c|c|}
\hline & $\begin{array}{c}\text { Path coefficients } \\
\text { (Bootsrapping) }\end{array}$ & $\begin{array}{c}T- \\
\text { Statistics }\end{array}$ & Sig & Conclusion \\
\hline leadership style - organizational commitment & 0.352 & 4.493 & 0.000 & H1 Accepted \\
\hline Competence - organizational commitment & 0.677 & 12.422 & 0.000 & H2 Accepted \\
\hline leadership style - employee performance & 0.433 & 5.554 & 0.000 & H3 Accepted \\
\hline Competence - employee performance & 0.294 & 3.091 & 0.002 & H4 Accepted \\
\hline $\begin{array}{c}\text { Organizational Commitment - Employee } \\
\text { performance }\end{array}$ & 0.296 & 4,693 & 0,000 & H5 Accepted \\
\hline
\end{tabular}

TABLE 7 : RESULT OF MEDIATION TESTING

\begin{tabular}{|c|c|c|c|c|c|c|}
\hline \multirow{2}{*}{ No } & \multirow{2}{*}{ Mediation Variable Organizational Commitment on: } & \multicolumn{4}{|c|}{ Effect of } & \multirow{2}{*}{ Ket } \\
\hline & & (A) & (B) & (C) & (D) & \\
\hline 1 & Leadership style $\left(\mathrm{X}_{1}\right)$ - Employee performance $\left(\mathrm{Y}_{2}\right)$ & $\begin{array}{l}0.385 \\
\text { (Sig) }\end{array}$ & $\begin{array}{l}0.741 \\
\text { (Sig) }\end{array}$ & $\begin{array}{l}0.622 \\
(\mathrm{Sig})\end{array}$ & $\begin{array}{l}0.562 \\
(\mathrm{Sig})\end{array}$ & $\begin{array}{c}\text { Partial } \\
\text { Mediation }\end{array}$ \\
\hline 2 & Competence $\left(\mathrm{X}_{2}\right)$ - Employee performance $\left(\mathrm{Y}_{2}\right)$ & $\begin{array}{l}0.162 \\
\text { (Sig) }\end{array}$ & $\begin{array}{l}0.743 \\
\text { (Sig) }\end{array}$ & $\begin{array}{l}0.815 \\
\text { (Sig) }\end{array}$ & $\begin{array}{l}0.678 \\
\text { (Sig) }\end{array}$ & $\begin{array}{c}\text { Partial } \\
\text { Mediation }\end{array}$ \\
\hline
\end{tabular}

The results of the analysis show that leadership style has a positive and significant effect on organizational commitment so that the analysis of this research model shows that the more appropriate the leadership style implementation style will lead to good employee organizational commitment.

Leadership has an influence on the survival of an organization. Kreitner and Kinicki [9] suggest that leadership is a process where an individual influences others to achieve common goals. Gibson et al. [6] suggest that leadership is an attempt to use influence to motivate individuals to complete several goals of an organization. The results of research by Walumbwa and Lawler [24] found that leadership style has a positive and significant effect on the level of organizational commitment. The same research results are shown by Sartika [17].
Statistically, it shows that competence has a positive and significant effect on organizational commitment so that the analysis of this research model shows that good competence will lead to good organizational commitment.

Byars and Rue [2] explain that competence is defined as a trait or characteristic needed by an office holder in order to carry out a position properly, or it can also mean that the characteristics / characteristics of a person are easily seen including the knowledge, expertise, and behavior that allows. to perform. As a consequence of this competency definition, the definition of competence refers to the ability of people to fulfill the requirements of their current or future roles. Thus, competence can also predict future performance because competence is an ongoing characteristic that generally cannot be lost [1]. 
Lotunani [11] in his research found that competence has a positive and significant effect on organizational commitment. Employees who already have good competence, the company will retain employees to continue working by providing salaries, benefits, and others that are in accordance with their competencies. Reciprocity is appropriate between the company and the employees who work, making employees commit to the company where they work now [5]. Research by Yamali [26] found competencies have a positive effect on organizational commitment.

The results of statistical data analysis show that the leadership style has a positive and significant effect on employee performance so that the analysis of this research model shows that an appropriate leadership style will lead to good employee performance.

Rivai [14] states that leadership style plays a very important role, it can even be said to be very decisive in achieving the goals previously set. Kasmir [8] also states that leadership style is one of several factors that affect employee performance. The leadership style between authoritarian and democratic leadership is certainly different. Through the leadership style, a leader can determine how to direct employees to achieve goals.

Based on the above opinion, it can be said that leadership style has a relationship and an influence on employee performance with a leadership style that is a role model for employees. Hakim Azizi's [7] research results concluded that leadership style has a positive and significant effect on employee performance. Similar results are shown by Tampi [22].

The results of statistical data analysis show that competence has a positive and significant effect on employee performance (path coefficient of 0.296 with a tstatistical value of 4.693) so that the analysis of this research model shows that good competence will lead to good employee performance.

Competence is a fundamental characteristic of each individual associated with criteria referenced to superior or effective performance in a job or situation. The underlying characteristics mean that competence is part of a person's personality that has been embedded and lasts a long time and can predict behavior in various tasks and work situations. Associated cause means that competence causes or predicts behavior and performance. Criteria benchmarks mean that competence actually predicts who does something well or badly, as measured by specific criteria or standards. These are a number of characteristics that underlie a person and show how to act, think, or generalize about a situation in the long term.

There are five types of competency characteristics, namely: (1) motives, something that is consistently thought of and desired, which causes one's actions; (2) traits or traits, physical characteristics and consistent responses to situations or information; (3) self-concept, attitudes, values or a picture of oneself; (4) knowledge, information that a person has in a specific area; (5) skills, a person's ability to perform certain physical or mental tasks. The results of research by Dhermawan [3] indicate that competence has a positive and significant effect on employee performance.
The results of statistical data analysis show that organizational commitment has a positive and significant effect on employee performance (path coefficient of 0.294 with a t-statistical value of 3.091) so that the analysis of this research model shows that good organizational commitment will lead to good employee performance. Organizational commitment is an important dimension of behavior that can be used to assess the tendency of employees to stay as members of the organization.

Employees with good organizational commitment have different attitudes than those with low commitment. Good organizational commitment results in job performance, low levels of absenteeism, and low employee turnover. Employees who are well committed will have good productivity [12]. Conversely, low employee commitment has a negative impact. Every organization will experience difficulties if employee commitment is low. Employees with low commitment will not give the best to the organization and will easily leave the organization.

There are several studies conducted by researchers that examine the relationship between organizational commitment and performance. The results of Efliani's (2014) [4] research entitled The Influence of Motivation, Organizational Culture and Organizational Commitment on Nurse Performance in Dr. Moewardi Surakarta found that most of the influences were evidenced by the $t$ value is greater than $t$ table $(3.294>1.985)$.

Furthermore, research was also carried out by Taurisa and Ratnawati [23] in the title Analysis of the Influence of Organizational Culture and Job Satisfaction on Organizational Commitment in Improving Employee Performance, which was carried out at PT. Sido Muncul Kaligawe Semarang found the results that there was a unidirectional influence between organizational commitment and employee performance. This shows that the better organizational commitment in the employees of PT. Sido Muncul, the better the employee's performance level. Another study was conducted by Supriyanto [18] with the results of his research finding that there is a significant positive effect between organizational commitment on employee performance, similar research results are shown in Mekta.

\section{CONCLUSION}

The conclusion of this research is that organizational commitment can relate the influence of leadership style and competence on employee performance at the Office of Investment and One Stop Services in Denpasar City. This indicates that organizational commitment can be a link between competency and performance variables with a partial mediating effect. This study was based on a relatively short time (cross-sectional). This limitation certainly results in the low generalization of the research. 


\section{REFERENCES}

[1] Amstrong,2014.Organisasi : Menuju Pencapaian Kinerja Optimum, Jakarta: Prasetya Mulya Publishing.

[2] Byars and Rue,2000. Skill and application.Mc Graw Hill.

[3] Dhermawan, AA. Ngurah Bagus. 2012. Pengaruh Motivasi, Lingkungan Kerja, Kompetensi dan Kompensasi Terhadap kepuasan Kerja Dan Kinerja Pegawai di Lingkungan Kantor Dinas Pekerjaan Umum Provinsi Bali. Jurnal Manajemen, Strategi Bisnis, dan Kewirausahaan Vol.6 No.2.

[4] Efliani, Destria (2014), Pengaruh Motivasi, Budaya Organisasi Dan Komitmen Organisasional Terhadap Kinerja Perawat Di RSUD Dr. Moewardi Surakarta, Tesis. Program Studi Magister Manajemen Program Pascasarjana Universitas Muhammadiyah Surakarta.

[5] Fadli, Uus Md, 2012, Pengaruh Kompetensi Karyawan Terhadap Komitmen Kerja Pada PT PLN (Persero) Rayon Rengasdengklok, Jurnal Manajemen Vol.09 No,2 Januari, 577-589.

[6] Gibson, James L, Donelly Jr. (2012) Organization Behavior, Structure, Process, Fourteenth Edition (International Edition) 1221 Avenue of the Americas, New York Ny.1002;Mc. Graw-Hill.

[7] Hakim Azizi (2015) Pengaruh gaya kepemimpinan terhadap kinerja pegawai badang pusat statistik di Kalimantan Barat work engagement sebagai varibel mediasi.Jurnal Ekonomi Universitas Tanjungpura. Vol1.No.2.

[8] Kasmir.2016.Manajemen Sumber Daya Manusia (Teori dan Praktik),Edisi 1. Jakarta : PT. RajaGrafindo Persada.

[9] Kreitner, Robert dan Angelo Kinicki. 2010.Organizational behavior. New York. Mc Graw Hill.

[10] Lor, W \& Hasan Z. 2017. The influence of leadership on employee performance among jewellery artisan in Malaysia. International Journal of accounting \& business management. Vol 5 No. April Page 4-33.

[11] Lotunani, Alamsyah, 2014, The Effect of Competence on Commitment, Performance and Satisfaction with Reward as a Moderating Variable (AStudy on Designing Work plans in Kendari City Government, Southeast Sulawesi), International Journal of Business and Management Invention Volume 3 Issue 2, February, 1825.

[12] Luthans, 2015. Perilaku Organisasi. Perilaku Organisasi, Jakarta Salemba.

[13] Moeheriono.2012.Pengukuran Kinerja Berbasis Kompetensi, Edisi Revisi.Jakarta: PT. Raja Grafindo Persada.

[14] Rivai,Veithzal dan Deddy Mulyadi. 2013. Kepemimpinan dan Perilaku Organisasi, Edisi Ketiga. Jakarta : PT. RajaGrafindo Persada.

[15] Robbins, 2015. Perilaku Organisasi, Buku 1 dan 2, Jakarta : Salemba Empat.

[16] Safitri,2014. Pengaruh independensi auditor dan gaya kepemimpinan terhapa kinerja auditor dengan komitmen organisasi sebagai variabel intervening. Journal imiah ekonomi dan bisnis Unilak. Vol 11. No.2 Tahun 2014.

[17] Sartika, 2014. Pengaruh kepausan kerja dan gaya kepemimpinan tranformasional terhadap keinginan keluar karyawan dengan komitmen organisasi sebagai variabel mediasi (Studi Di CV Putra Tama Jaya). Management analysis juournal Vol.3 No.2 2014.

[18] Supriyanto, Edy, 2015, Pengaruh Penetapan Sasaran dan Sistem Remunerasi terhadap Kinerja Pegawai Organisasi sektor Publik, Jurnal Manajemen, Universitas Brawijaya, Malang

[19] Suwatno dan Donni Juni Priansa. 2016. Manajemen SDM dalam Organisasi Publik dan Bisnis.Bandung : Alfabeta.

[20] Ni Kadek Suryani and John E.H.J. Foeh, 2019, Impact of Organizational Justice on Organizational Performance in the Hospitality Industry, Journal of Engineering and Applied Sciences, Volume:14, Issue:12, pp: $4124-4131$.

[21] Ni Kadek Suryani dan Gede Agus Dian Maha Yoga, 2018, Konflik dan Stress Kerja dalam Organisasi, 2018, Jurnal Widya Manajemen, Vol. 1 No.1, November 2018, pp: $99-113$.

[22] Tampi. 2016. Pengaruh Gaya Kepemimpinan dan Motivasi Terhadap Kinerja Karyawan Pada PT. Bank Negara Indonesia Tbk (Regional Sales Manado). Jurnal Acta Diurna Vol. III No.4.

[23] Taurisa dan Intan Ratnawati, 2012.Analisis Pengaruh Budaya Organisasi dan Kepuasan Kerja terhadap Komitmen Organisasiona dalam Meningkatkan Kinerja Karyawan,Jurnal Bisnis dan Ekonomi, Vol. 19, No. 2, 2012.

[24] Walumbwa F. and Lawyer J. (2013). Building Effective Organizations: Transformational Leadership, Collectivist Orientation, Work-Related Attiudes and Withdrawal Behaviours in Three Emerging Economies. The International Journal of Human Resource Management. Vol.14,No.7, pp.1083-1101.
[25] Wibowo, 2016.Manajemen Kinerja, Edisi Keempat.Jakarta:PT. Raja Grafindo Persada.

[26] Yamali, 2017. Pengaruh Kompensasi Dan Kompetensi Terhadap Komitmen Organisai Serta Implikasinya Terhadap Kinerja Tenaga Ahli Perusahaan Jasa Konstruksi Di Provinsi Jambi. Journal of economic and business Vol1. No.1 2017. 
EJBMR, European Journal of Business and Management Research Vol. 5, No. 5, September 2020 